\title{
Clinical Significance of Platelet Antigen 1/Platelet Antigen 2 (PIA1/A2) Polymorphism of Integrin $\beta 3$ (ITGB3) Gene in Coronary Artery Disease
}

\author{
HALA ABDEL AL, M.D.*; SOMIA A. BAWADY, M.D.*; AZZA A. SAAB, M.D.*; WAEL EL KILANY, M.D.**; \\ AHMED S. ALLAM, M.D.*** and SHAIMAA S. METWALLY, M.Sc.*
}

The Departments of Clinical Pathology*, Cardiology** and Internal Medicine***, Faculty of Medicine, Ain Shams University, Egypt

\begin{abstract}
Background: Coronary Artery disease (CAD) is the leading cause of death worldwide. Platelet activation and aggregation play a crucial role in the process of arterial thrombosis; the main pathogenesis of the disease. The major membrane protein on platelet is integrin $\alpha_{\mathrm{IIb}} \beta_{3}$ which mediates this response by rapidly transiting from its resting to an activated state in which it serves as a receptor for ligands that can bridge platelets together.
\end{abstract}

Aim of Study: The aim of the present study was to assess the relationship between Platelet Antigen 1/Platelet Antigen 2 (P1A1/A2) polymorphism of ITGB3 gene and CAD.

Patients and Methods: The study was conducted on 55 CAD patients in addition to 55 age-and sex-matched healthy subjects serving as a healthy control group. Patients were subdivided into three subgroups according to the degree of disease severity based on the number of occluded coronary blood vessels as seen by the coronary angiography (subgroup Ia: Patients with one-vessel occlusion, subgroup Ib: Patients with two-vessel occlusion and subgroup Ic: Patients with three-or more-vessel occlusion). Determination of the P1A1/A2 polymorphism of ITGB3 gene was carried out using Restriction Fragment Length Polymorphis-Polymerase Chain Reaction (RFLP-PCR).

Results: The results of the present study revealed that $\mathrm{PlA} 1 / \mathrm{P} 1 \mathrm{~A} 2$ genotype and P1A2 allele were more frequent in CAD patients as compared to controls; however such difference in frequency was not statistically significant. No significant difference was detected between the genotype distributions among the different degrees of CAD severity. Moreover, no significant difference was found between both genotypes as regards the presence of risk factors. Finally, the heterozygous genotype PlA1/PlA2 was associated with male sex and increased total cholesterol level.

Conclusion: PlA1/P1A2 polymorphism of ITGB3 gene failed to prove any association with CAD.

Correspondence to: Dr. Hala Abdel Al, The Department of Clinical Pathology, Faculty of Medicine, Ain Shams University, Egypt
Key Words: Coronary artery disease - ITGB3 gene - PlA1/ PlA2 polymorphism $-P C R-R F L P$.

\section{Introduction}

CORONARY Artery Disease (CAD) remains a leading cause of death worldwide despite of the scientific advancements in the understanding of its pathophysiology [1]. In Egypt, CAD is responsible for $21 \%$ of all deaths and its prevalence rate is $8.3 \%$ [2]. It is a multifactorial complex chronic inflammatory disease where atherosclerosis and its superimposed thrombosis result in the occlusion of the coronary arteries and the occurrence of CAD [3]. Platelets contribute to the initiation of atherosclerosis through interaction with other cells including endothelial cells and leukocytes. Moreover, upon rupture of the atherosclerotic lesion, platelet activation and subsequent aggregation at the site of injury lead to thrombosis and vessel occlusion, resulting in the disease. Platelet integrin $\alpha_{\mathrm{IIb}} \beta_{3}$ is the dominant membrane protein expressed on platelets. Platelet activation renders integrin $\alpha_{\text {IIb }} \beta_{3}$ active and thus integrin $\alpha_{\text {IIb }} \beta_{3}$ binds its ligand, fibrinogen, bridging platelets together $[4,5]$. Glycoprotein IIb $\left(\alpha_{\mathrm{IIb}}\right)$ and glycoprotein IIIa $\left(\beta_{3}\right)$ are the non-covalently bound subunits of the single membrane glycoprotein IIb-IIIa (integrin $\alpha_{\text {IIb }} \beta_{3) ~[6]}$

Glycoprotein IIIa or the beta subunit of the platelet integrin is coded by the integrin $\beta_{3}$ (ITGB3) gene [3]. PlA1/PlA2 is a common polymorphism of ITGB3 gene. In the P1A2 allelic isoform, thymine to cytosine nucleotide transition occurs at codon 33 of exon 2 of the ITGB3 gene corresponding to substitution of proline for leucine in the mature GP IIIa [7]. The P1A1/P1A2 polymorphism of 
ITGB3 gene was reported to influence platelet activation, aggregation, and post-occupancy signaling by $\alpha_{\mathrm{IIb}} \beta_{3}$ where there is increase in the binding affinity of platelet to fibrinogen in subjects with the PlA2 allele as well as increase in platelet aggregation in response to epinephrine, adenosine diphosphate and collagen in-vitro [8]. Moreover, carotid plaque morphology examined by magnetic resonance imaging showed that subjects who carried the PlA2 allele were found to have plaques with thinner fibrous caps, and these thinner caps represent the major precursor lesion for CAD [9]

Aim of the work: The aim of the present study was to to assess the relationship between PIA1/PIA2 polymorphism of ITGB3 gene and CAD.

\section{Material and Methods}

Subjects in this study were recruited from the Angiography Unit at the Cardiology Department of Ain Shams University from January 2017 till January 2018, Cairo, Egypt. Informed written consent was obtained from each participant before enrolment in the study. Moreover, the study was approved by the Research Ethics Committee of Ain Shams University. The study included 110 subjects who underwent coronary angiography. According to the results of coronary angiography, the included subjects were classified into: 55 patients with atherosclerotic CAD serving as patients' group in addition to 55 age-and sex-matched subjects proven to be coronary artery disease-free by coronary angiography and serving as a healthy control group. Patients suffering from type 2 diabetes mellitus or any malignancy were excluded from the study.

Full history was taken from all individuals included in this study with special emphasis on history of smoking, hypertension, and family history of CAD together with thorough clinical examination with special emphasis on cardiological examination. Weight and height of all individuals in the study were taken to calculate body mass index [BMI=weight $(\mathrm{Kg}) /$ height $\left.^{2}\left(\mathrm{~m}^{2}\right)\right]$.

Five milliliters of venous blood were withdrawn under complete aseptic conditions subsequent to 10-12 hours fasting from patients and controls (prior to angiography). Three $\mathrm{mL}$ of blood were put into a sterile plain vacutainer, left to clot for 30 minutes, centrifuged (at 4000rpm for 10 minutes) and the separated serum was used for the assay of lipid profile. The remaining two milliliters of blood were put into a sterile $\mathrm{K}_{3}$ EDTA vacutainer for ITGB3 polymorphism detection.
Lipid profile [Total Cholesterol (TC), Triglycerides (TG), and High Density Lipoprotein-Cholesterol (HDL-C)] were analyzed on the Beckman coulter AU 480 system (Beckman coulter, Inc. 250s. Kraemer Blvd. Brea, CA92821, USA) by enzymatic method, while Low Density LipoproteinCholesterol (LDL-C) was calculated using Friedwald equation.

ITGB3 gene polymorphism (P1A1/PIA2): DNA extraction was performed using GeneJET Whole Blood Genomic DNA Purification Mini Kit supplied by Thermo Scientific (Thermoscientific, 168 Third Avenue, Waltham, MA, USA) and kept at $-20^{\circ} \mathrm{C}$ until required. ITGB3 gene polymorphism (PIA1/PIA2) was determined by PCR-RFLP. Amplification by PCR was performed in a DNA thermocycler ( Prime thermal cycler). The test primers and the hot start master mix were supplied by Thermo Scientific (Thermoscientific, 168 Third Avenue, Waltham, MA, USA). The forward primer was 5'GCTCCAATGTACGGGGTAAAC3' and the reverse primer was 5'GCTCCAATGTACGGGGTAAAC3'. The reaction mixture (25 L) consisted of 12.5 bot start master mix, 1 a forward primer, 1 Loverse primer, 10 LNA template and 0.5 nuclease-free water. The PCR conditions were as follows: An initial 4 minutes denaturation at $95^{\circ} \mathrm{C}$, then thermocycling at $94^{\circ} \mathrm{C}$ for 30 seconds, $59^{\circ} \mathrm{C}$ for 30 seconds, and $72^{\circ} \mathrm{C}$ for 60 seconds ( 35 cycles), with subsequent final extension at $72^{\circ} \mathrm{C}$ for 10 minutes. Samples were digested using the restriction enzyme FastDigest MspI (Thermo Scientific, USA) at $37^{\circ} \mathrm{C}$ for 15 minutes. The polymorphic PlA2 allele has one restriction site and produces two fragments of 125 and $157 \mathrm{bp}$. DNA detection was performed by $2 \%$ agarose gel electrophoresis and stained by ethidium bromide Fig. (1).

Statistical analysis was performed using statistical soft-ware programme IBM SPSS statistics (Version 25.0, IBM Corp., USA, 2017). Qualitative data were expressed as number and percent (n, \%); parametric quantitative data were expressed as mean and Standard Deviation (SD). Comparative statistics between two independent groups were done by Chi-square test $(\chi)$ for qualitative data and Student's $t$-test for quantitative parametric data. Genotype distribution was investigated in relation to Hardy-Weinberg Equilibrium (HWE) by applying Chi square Test $\left(\chi^{2}\right) . p<0.05$ was considered significant. Logistic multi-regression analysis was applied to search for panel independent parameters (CAD risk factors) that can predict the target parameter dependent variable (ITGB3 polymorphism). 


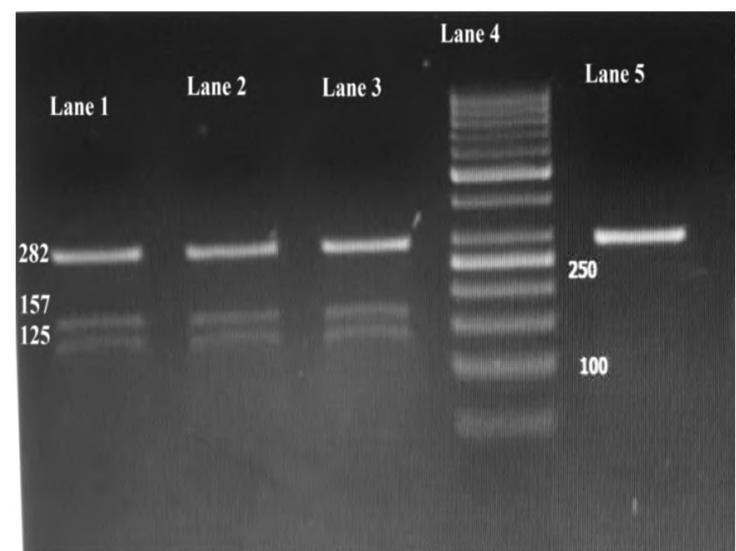

Fig. (1): Gel electrophoresis of P1A1/P1A2 polymorphism genotypes. Lanes (1, 2, and 3): Heterozygous (TC) $(125,157$ and 282bp), lane 4: Molecular weight marker (50bp ladder), and lane 5: Homozygous wild (TT) (282bp)

\section{Results}

The descriptive and comparative statistics of demographic, clinical, and routine laboratory data of all participants in the study are included in (Table 1). A significant difference was found between patient and control as regards smoking, hypertension, family history and BMI. A nonsignificant difference was found between both groups as regards lipid profile (TC, TG, HDL-C and LDL-C) ( $p>0.05$ respectively). Within the patients' group, $27.3 \%$ of the patients had a positive family history of CAD, $61.8 \%$ suffered from premature CAD and most of patients had only one occluded coronary blood vessel (52.7\%).

The descriptive and comparative statistics of the genotype and allele frequencies of the studied polymorphism in patients and controls are presented in (Table 2). PlA1/PlA1 (TT) genotype and PlA1 (T) allele were less frequent in CAD patients as compared to controls $(72.7 \%$ Vs. $83.6 \%$ and $86.4 \%$ Vs. 91.8\% respectively); however such difference in frequency was not statistically significant ( $p>0.05$ respectively). Moreover, P1A1/P1A2 (TC) genotype and PlA2 (C) allele were more frequent in CAD patients as compared to controls $(27.3 \%$ Vs. $16.4 \%$ and $13.6 \%$ Vs. $8.2 \%$ respectively); however such difference in frequency was not statistically significant ( $p>0.05$ respectively). P1A2/P1A2 (CC) genotype was not identified.

Table (3) shows the descriptive and comparative statistics between the different degrees of CAD severity and P1A1/P1A2 genotypes among the patients' group. A non-statistical significant difference was found in the genotype distribution among the different degrees of severity of CAD $\left(\chi^{2}=1.08, p\right.$ $>0.05$ ).
Table (1): Descriptive and comparative statistics of demographic, clinical, and routine laboratory data of all participants using Student's $t$-test for quantitative data and Chi-square test for qualitative data.

\begin{tabular}{|c|c|c|c|}
\hline \multirow[t]{2}{*}{ Parameters } & $\begin{array}{c}\text { Patients } \\
\mathrm{n}=55\end{array}$ & $\begin{array}{c}\text { Controls } \\
n=55\end{array}$ & \multirow{2}{*}{$\begin{array}{c}p- \\
\text { value }\end{array}$} \\
\hline & \multicolumn{2}{|c|}{$\mathrm{n}(\%) / \mathrm{X} \pm \mathrm{SD}^{*}$} & \\
\hline Age (years) & $59.4 \pm 9.8^{*}$ & $57.6 \pm 7.3^{*}$ & 0.340 \\
\hline Male sex & $47(85.5 \%)$ & $49(89 \%)$ & 0.567 \\
\hline $\begin{array}{l}\text { Body mass index }\left(\mathrm{Kg} / \mathrm{m}^{2}\right) \text { : } \\
\text { Normal }(18.5-24.9) \\
\text { Overweight }(25-29.9) \\
\text { Obese }(\geq 30)\end{array}$ & $\begin{array}{ll}8 & (14.5 \%) \\
27(49.1 \%) \\
20(36.4 \%)\end{array}$ & $\begin{array}{l}39(70.9 \%) \\
10(18.2 \%) \\
6 \quad(10.9 \%)\end{array}$ & 0.345 \\
\hline Hypertension $(>140 / 90 \mathrm{mmHg})$ & $21(38.2 \%)$ & $0 \%$ & 0.00 \\
\hline $\begin{array}{l}\text { Smoking: } \\
\text { Non-smoker } \\
\text { Former smoker } \\
\text { Current smoker }\end{array}$ & $\begin{array}{l}20(36.3 \%) \\
14(25.5 \%) \\
21(38.2 \%)\end{array}$ & $\begin{array}{l}39(70.9 \%) \\
6 \quad(10.9 \%) \\
10(18.2 \%)\end{array}$ & 0.00 \\
\hline Positive family history of CAD & $15(27.3 \%)$ & $5 \quad(9.1 \%)$ & 0.013 \\
\hline $\begin{array}{l}\text { Premature } C A D: \\
\text { - (CAD in male }<55 \text { years or in } \\
\text { female }<65 \text { years })\end{array}$ & $34(61.8 \%)$ & - & - \\
\hline $\begin{array}{l}\text { CAD severity (number of occluded } \\
\text { coronary vessels): } \\
\text { Subgroup Ia ( } 1 \text { vessel) } \\
\text { Subgroup Ib ( } 2 \text { vessels }) \\
\text { Subgroup Ic ( } \geq 3 \text { vessels })\end{array}$ & $\begin{array}{l}29(52.7 \%) \\
13(23.65 \%) \\
13(23.65 \%)\end{array}$ & - & - \\
\hline $\begin{array}{l}\text { Lipid profile: } \\
\text { - Total cholesterol }(\mathrm{mg} / \mathrm{dL}) \text { : } \\
\text { Normal }(<200) \\
\text { Borderline }(200-239)\end{array}$ & $\begin{array}{l}49(89.1 \%) \\
6 \quad(10.9 \%)\end{array}$ & $\begin{array}{l}48(87.3 \%) \\
7 \quad(12.7 \%)\end{array}$ & 0.768 \\
\hline $\begin{array}{l}\text { - Triglycerides }(\mathrm{mg} / \mathrm{dL}) \text { : } \\
\text { Normal }(<150) \\
\text { Borderline }(150-199)\end{array}$ & $\begin{array}{l}41(74.5 \%) \\
14(25.5 \%)\end{array}$ & $\begin{array}{l}45(81.8 \%) \\
10(18.2)\end{array}$ & 0.356 \\
\hline $\begin{array}{l}\text { - } H D L-C(m g / d L) \text { : } \\
\text { - Normal }(40-50 \text { in males, } 50-59 \\
\text { in females) } \\
\text { - Low ( }<40 \text { males, }<50 \text { females })\end{array}$ & $\begin{array}{l}53(96.4 \%) \\
2(3.6 \%)\end{array}$ & $\begin{array}{l}49(89.1 \%) \\
6(10.9 \%)\end{array}$ & 0.142 \\
\hline $\begin{array}{l}\text { - } L D L-C(m g / d L): \\
\quad \text { Normal }(<100) \\
\text { High }(>100)\end{array}$ & $\begin{array}{l}36(65.5 \%) \\
19(34.5 \%)\end{array}$ & $\begin{array}{l}40(72.7 \%) \\
15(27.3 \%)\end{array}$ & 0.409 \\
\hline
\end{tabular}

CAD : Coronary Artery Disease.

HDL-C : High Density Lipoprotein Cholesterol.

LDL-C : Low Density Lipoprotein Cholesterol

$p>0.05$ : Non-significant. $\quad p<0.05$ : Significant.

Table (2): Descriptive and comparative statistics of genotype and allele frequencies of P1A1/P1A2 polymorphism in patients and controls using chi-square test.

\begin{tabular}{|c|c|c|c|c|}
\hline \multirow{2}{*}{$\begin{array}{l}\text { PlA1/PlA2 } \\
\text { polymorphism }\end{array}$} & \multicolumn{2}{|c|}{$\begin{array}{c}\text { Genotype frequency } \\
\text { n }(\%)\end{array}$} & \multicolumn{2}{|c|}{$\begin{array}{c}\text { Allele frequency } \\
\text { n (\%) }\end{array}$} \\
\hline & TT & $\mathrm{TC}$ & $\mathrm{T}$ & $\mathrm{C}$ \\
\hline $\begin{array}{l}\text { - CAD patients } \\
(\mathrm{n}=55)\end{array}$ & $40(72.7 \%)$ & $15(27.3 \%)$ & $95(96.4 \%)$ & $15(13.6 \%)$ \\
\hline $\begin{array}{l}\cdot \text { Controls }(\mathrm{n}=55) \\
\cdot \chi^{2} \\
\cdot p \\
\cdot \text { Odds ratio }(95 \% \\
\text { CI })\end{array}$ & $\begin{array}{c}46(83.6 \%) \\
1.92 \\
0.17 \\
0.52(0.2\end{array}$ & $\begin{array}{l}9(16.4 \%) \\
21-1.32)\end{array}$ & \multicolumn{2}{|c|}{$\begin{array}{c}101(91.8 \%) 9(8.2 \\
1.30 \\
>0.05\end{array}$} \\
\hline $\begin{array}{l}\mathrm{T} \text { : Thymine. } \\
\mathrm{C} \text { : Cytosine. }\end{array}$ & & $\begin{array}{l}\mathrm{CAD}: \mathrm{C} \\
p>0.05: \mathrm{N}\end{array}$ & $\begin{array}{l}\text { Coronary Art } \\
\text { Jon-significe }\end{array}$ & y Disease. \\
\hline
\end{tabular}


Table (3): Descriptive and comparative statistics between PlA1/P1A2 genotypes in the different subgroups of CAD patients using Chi-square test.

\begin{tabular}{lcccc}
\hline $\begin{array}{l}\text { CAD severity (number of } \\
\text { occluded coronary vessels) }\end{array}$ & $\begin{array}{c}\mathrm{TT} \\
\mathrm{n}(\%)\end{array}$ & $\begin{array}{c}\mathrm{TC} \\
\mathrm{n}(\%)\end{array}$ & $\chi^{2}$ & $p$ \\
\hline - Subgroup Ia (one vessel) & $22(55 \%)$ & $7(46.7 \%)$ & 1.08 & 0.58 \\
- Subgroup Ib (two vessels) & $10(25 \%)$ & $3(20 \%)$ & & \\
- Subgroup Ic (three or more & $8(20 \%)$ & $5(33.3 \%)$ & & \\
vessels) & & & \\
\hline $\mathrm{T}:$ Thymine. & CAD & : Coronary Artery Disease. & \\
C: Cytosine. & $p>0.05$ : Non-significant. & &
\end{tabular}

Statistical comparison between TT and TC genotypes as regards the presence of risk factors among the patients' group revealed a non-statistical significant difference between both genotypes ( $p>0.05$ respectively) (Table 4$)$.

Table (4): Comparative statistics between TT and TC genotypes as regards the CAD risk factors among patients' group using student's $t$-test for quantitative risk factors and Chi-square test for qualitative risk factors.

\begin{tabular}{|c|c|c|c|c|}
\hline Parameters & $\begin{array}{l}\mathrm{TT}(\mathrm{n}=40) \\
-\mathrm{n}(\%) / \\
\mathrm{X} \pm \mathrm{SD}^{* *}\end{array}$ & $\begin{array}{c}\mathrm{TC}(\mathrm{n}=15) \\
-\mathrm{n}(\%) / \\
\mathrm{X} \pm \mathrm{SD}^{* *}\end{array}$ & $\chi_{t_{*}}^{2 /}$ & $p$ \\
\hline Age (years) & $58.6 \pm 8.9^{* *}$ & $60.9 \pm 7.8 * *$ & 0.45 & $5 * 0.23$ \\
\hline $\begin{array}{l}\text { Female } \\
\text { Male }\end{array}$ & $\begin{array}{l}4(10 \%) \\
36(90 \%)\end{array}$ & $\begin{array}{l}4(26.7 \%) \\
11(73.3 \%)\end{array}$ & $2.44 \mathrm{C}$ & 0.12 \\
\hline $\begin{array}{l}\text { Family history: } \\
\text { Negative } \\
\text { Positive }\end{array}$ & $\begin{array}{l}29(72.5 \%) \\
11(27.5 \%)\end{array}$ & $\begin{array}{l}11(73.3 \%) \\
4(26.7 \%)\end{array}$ & $0.01 \mathrm{C}$ & 0.95 \\
\hline $\begin{array}{l}\text { Classic CAD } \\
\text { Premature CAD }\end{array}$ & $\begin{array}{l}14(35 \%) \\
26(65 \%)\end{array}$ & $\begin{array}{l}7(46.7 \%) \\
8(53.3 \%)\end{array}$ & $0.63 \mathrm{C}$ & 0.43 \\
\hline $\begin{array}{l}\text { Smoking: } \\
\text { Non-smoker } \\
\text { Former smoker } \\
\text { Current smoker }\end{array}$ & $\begin{array}{l}13(32.5 \%) \\
10(25 \%) \\
17(42.5 \%)\end{array}$ & $\begin{array}{l}7(46.7 \%) \\
4(26.7 \%) \\
4(26.7 \%)\end{array}$ & $1.33 \mathrm{C}$ & 0.51 \\
\hline $\begin{array}{l}\text { Hypertension: } \\
\text { Negative } \\
\text { Positive }\end{array}$ & $\begin{array}{l}25(62.5 \%) \\
15(37.5 \%)\end{array}$ & $\begin{array}{l}9(60 \%) \\
6(40 \%)\end{array}$ & $0.03 \mathrm{C}$ & 0.87 \\
\hline $\begin{array}{l}\text { Body mass index }\left(\mathrm{Kg} / \mathrm{m}^{2}\right) \text { : } \\
\text { Normal }(18.5-24.9) \\
\text { Overweight }(25-29.9) \\
\text { Obese }(\geq 30)\end{array}$ & $\begin{array}{l}7(17.5 \%) \\
19(47.5 \%) \\
14(35 \%)\end{array}$ & $\begin{array}{l}1(6.7 \%) \\
8(53.3 \%) \\
6(40 \%)\end{array}$ & $\begin{array}{r}1.03 \mathrm{C} \\
\mathbf{C}\end{array}$ & 0.59 \\
\hline $\begin{array}{l}\text { Total cholesterol }(\mathrm{mg} / \mathrm{dL}) \text { : } \\
\quad \text { Normal }(<200) \\
\text { Borderline }(200-239)\end{array}$ & $\begin{array}{l}3(7.5 \%) \\
37(92.5 \%)\end{array}$ & $\begin{array}{l}3(20 \%) \\
12(80 \%)\end{array}$ & $1.75 \mathrm{C}$ & 0.19 \\
\hline $\begin{array}{l}\text { Triglycerides }(\mathrm{mg} / \mathrm{dL}) \text { : } \\
\quad \text { Normal }(<150) \\
\text { Borderline }(150-199)\end{array}$ & $\begin{array}{l}10(25 \%) \\
30(75 \%)\end{array}$ & $\begin{array}{l}4(26.7 \%) \\
11(73.3 \%)\end{array}$ & $0.02 \mathrm{C}$ & 0.89 \\
\hline $\begin{array}{l}H D L-C(m g / d L): \\
\cdot \text { Normal }(40-50 \text { in males, } \\
50-59 \text { in females }) \\
\cdot \text { Low (<40 males, }<50 \\
\text { females) }\end{array}$ & $\begin{array}{l}1(25 \%) \\
39(97.5 \%)\end{array}$ & $\begin{array}{l}1(6.7 \%) \\
14(93.3 \%)\end{array}$ & 0.54 & 0.46 \\
\hline $\begin{array}{l}L D L-C(m g / d L): \\
\text { Normal }(<100) \\
\text { High }(>100)\end{array}$ & $\begin{array}{l}16(40 \%) \\
24(60 \%)\end{array}$ & $\begin{array}{l}5(33.3 \%) \\
10(66.7 \%)\end{array}$ & 0.21 & 0.65 \\
\hline
\end{tabular}

Logistic stepwise multi-regression analysis revealed that the heterozygous genotype TC is associated with male sex and increased total cholesterol level $(\mathrm{F}-\mathrm{ratio}=3.29, p=0.04)$.

\section{Discussion}

Coronary artery disease is a complex multifactorial disease where atherosclerosis and its subsequent thrombosis are the underlying cause of the disease [10]. The activation of platelet together with its surface fibrinogen receptor, integrin $\alpha_{\mathrm{IIb}} \beta_{3}$, plays a crucial role in the process of arterial thrombosis and hence its role in the development of CAD. Glycoprotein IIIa ( $\beta_{3}$ subunit of integrin $\alpha_{\text {IIb }} \beta_{3}$ ) is encoded by ITGB3 gene [11]. Previous researches focusing on the association of PlA1/P1A2 polymorphism of the ITGB3 gene with CAD in various ethnic groups are contradictory and are still debated $[2,12]$. Accordingly, the present casecontrol study was designed to evaluate the relationship between P1A1/P1A2 polymorphism of ITGB3 gene and $\mathrm{CAD}$ in a group of Egyptian patients and controls.

In our study, most of CAD patients were smokers and overweight. These findings strengthened the fact that the environmental factors and the patient lifestyle are major traditional risk factors for the disease development [13] . A non-statistical significant difference was observed between CAD patients and controls regarding the lipid profile being almost normal in both groups. This result is attributed to the patients' intake of lipid lowering drugs.

Our study demonstrated the presence of homozygous P1A1/P1A1 and heterozygous P1A1/P1A2 genotypes among all participants; meanwhile the homozygous P1A2/P1A2 genotype was completely absent. Such results were not surprising as some previous stuldies had reported such unusualPIAA genotype distribution characterized by the complete absence of homozygousP1A2/P1A2 [14,15] .

The application of Hardy-Weinberg law proved the genetic equilibrium of the studied population regarding the distribution of the studied genotypes.

Data of our study revealed that the heterozygous P1A1/P1A22 genotype andP1A2 allele ofP1A1/P1A22 polymorphism were more frequent in CAD patients as compared to controls(P1A1/P1A2:: $27.3 \%$ Vs. 16.4\%;P1A2:: 13.6\% Vs. 8.2\%). However, such difference in frequency was not statistically significant. This data is in accordance with an American community-based case-cohort study by Aleksic and his colleagues, [12]1 which revealed a non- 
significant increase in the risk of CAD in individuals heterozygous or homozygous for the PlA2 allele. The PlA1/PlA2 and PlA2/P1A2 genotypes constituted $26.9 \%$ of cases as compared to $25.9 \%$ of healthy subjects. Moreover, a meta-analysis study performed by Zhu et al., [16] who combined data from several separate studies done on Caucasian populations found that the overall PlA1/P1A2 and PlA2/PlA2 genotypes constituted $28.4 \%$ of the patients and $27.2 \%$ of the controls. Hence, the study concluded that the PIA2 allele was not a risk factor for acute coronary syndrome.

The Helsinki Sudden Death Study which was conducted on the sudden out-of hospital unexpected deaths revealed that the carriage of the PlA2 allele was significantly associated with acute coronary thrombosis in those diagnosed with sudden cardiac death [17]. Accordingly, there is a mortality bias where almost third of individuals with a first major coronary event die out-of-hospital and hence are not included in studies [18]

On the other hand, a meta-analysis performed by Floyd et al., [9] showed increased risk of CAD and myocardial infarction in carriers of the PIA2 allele. Moreover, the results of a study done by Khatami et al., [3] suggested that the polymorphic variant PlA1/PlA2 was associated with CAD in the Iranian population where PIA1/P1A2 and PIA2/ PlA2 genotypes constituted $33.3 \%$ of the patients and $17.2 \%$ of the controls. Several factors could contribute to the aforementioned discrepancies as different ethnicity that affects the polymorphism frequency, different study designs, and publication bias toward positive results in small studies. Later study by Fawzy et al., [2] on 23 Egyptian patients with stable CAD undergoing diagnostic coronary angiography and 34 controls, found a significant higher prevalence of PlA1/PlA2 and PlA2/PlA2 genotypes among CAD patients compared to controls. The PlA1/P1A2 genotype was $34.8 \%$ in the patients Vs. $23.5 \%$ in the controls; meanwhile the $\mathrm{PlA} 2 / \mathrm{PlA} 2$ genotype was $8.7 \%$ in the patients and $0 \%$ in the controls. However, several limitations of the study were mentioned by the author himself that should be taken into consideration. First, coronary angiography was not performed for the controls in this study and accordingly, some of the controls could have had a subclinical atherosclerosis that affected the true risk associated with the PIA2 allele. Second, the included patient population was relatively of small sample size which might play a role in the discrepancy between their results and ours. Such conflicting results could be referred to the complexity of the disease and to the presence of different mechanisms underlying plaque rupture and thrombosis. As the CAD is a complex multifactorial disease, the PlA role in the pathogenesis of CAD is largely dependent on other factors that influence the impact of any altered PIA phenotype and the disease outcome depends on the sum of other multiple interacting factors determining the disease severity [2]. Thus, the identification of a contribution by a single gene polymorphism to a multifactorial, polygenic pathological process is challenging and requires a very large sample size [19].

In our study, severity of CAD was evaluated using the coronary angiography to detect the number of occluded coronary vessels. No relation was found between the type of genotype present and the number of occluded coronary vessels. Similar data were reported by Grove et al., [20] and Le Hello et al., [21] who proved that the ITGB3 gene genotypes have no influence on the disease severity. By contrast, study performed by Galasso and his colleagues [22] noticed that CAD patients with PIA2 allele had a worse prognosis with a higher incidence of re-infarction and/or cardiac death than PIA2 negative patients. However, the authors could not rule out the presence of possible linkage disequilibrium which might explain their results.

The study investigated the differences between the PlA1/PIA2 and PlA1/PlA1 genotypes in relation to the conventional risk factors (age, sex, smoking, hypertension, obesity, dyslipidemia, and positive family history of CAD). No significant differences were found between both genotypes and the presence of CAD risk factors. These results were in agreement with those of Le Hello et al., [21] and Galasso and his colleagues [22]; who concluded that the PIA1/PIA2 polymorphism is not associated with the presence of any conventional CAD risk factors.

Logistic stepwise multi-regression analysis was applied to evaluate the association between PlA1/ PlA2 polymorphism and the risk factors of CAD. The analysis revealed that the heterozygous genotype PlA1/PlA2 is more likely to be combined with male sex and high total cholesterol level.

\section{In Conclusion:}

The present study revealed the absence of significant differences in the genotype frequencies of PlA1/PlA2 polymorphism of the ITGB3 gene in CAD patients as compared to controls although being higher in the former group. Moreover, the different genotypes of the ITGB3 gene were not associated with any separate risk factor. Meanwhile, 
the heterozygous P1A1/P1A2 genotype tends to be more frequent in male patients who have a high cholesterol level.

Further multi-ethnic studies on larger sample sizes with wide range of age groups will be needed to verify these findings in the future. Prospective longitudinal studies are recommended to study the association of PlA1/PIA2 polymorphism with CAD, to evaluate its contribution in the pathogenesis of the disease, and its association with other risk factors of CAD as hypertension and smoking. This will help in developing novel strategies for early screening of individuals at risk and early management of patients with CAD. Further evaluation of ITGB3 gene polymorphisms other than PlA1/PlA2 and their association with CAD is also recommended. Application of new modalities for genotyping single nucleotide polymorphism as tetra primer amplification refractory mutation system (TARMS-PCR) is also recommended where genotyping can be done using only a thermocycler machine at the least time. Interaction of multiple genes that are in linkage disequilibrium and simultaneous studies of different genes may reveal associations that at present seem to be weak.

\section{Grant information:}

The authors declared that no grants were involved in supporting this work.

\section{References}

1- KANDASWAMY E. and ZUO L.: Recent advances in treatment of coronary artery disease: Role of science and technology. Int. J. Mol. Sci., 19: 424-41. doi: 10.3390/ ijms19020424, 2018.

2- FAWZY M.S., TORAIH E.A., ALY N.M., FAKHRELDEEN A., BADRAN D.I. and HUSSEIN M.H.: Atherosclerotic and thrombotic genetic and environmental determinants in Egyptian coronary artery disease patients: A pilot study. BMC Cardiovasc. Disord., 17: 26-44. doi: 10.1186/s12872-016-0456-3, 2017.

3- KHATAMI M., HEIDARI M.M. and SOHEILYFAR S. Common rs5918 (PlA1/A2) polymorphism in the ITGB3 gene and risk of coronary artery disease. Arch. Med. Sci. Atheroscler. Dis., 1: e9-e15. Doi: 10.5114/amsad.2016. 59587, 2016.

4- XU X.R., WANG Y., ADILI R., JU L., SPRING C.M., et al.: Apolipoprotein A-IV binds $\alpha_{\mathrm{IIb}} \beta_{3}$ integrin and inhibits thrombosis. Nat. Commun., 9: 3608-25. doi: 10.1038/ s41467-018-05806-0, 2018.

5- ZHANG Y., QIU Y., BLANCHARD A.T., CHANG Y., BROCKMAN J.M., MA V.P., LAM W.A. and SALAITA K.: Platelet integrins exhibit anisotropic mechanosensing and harness piconewton forces to mediate platelet aggregation. Proc. Natl. Acad. Sci., 115: 325-30. doi: 10.1073/ pnas. $1710828115,2018$.
6- ESTEVEZ B., SHEN B. and DU X.: Targeting integrin and integrin signaling in treating thrombosis. Arterioscler. Thromb. Vasc. Biol., 35: 24-9. doi: 10.1161/ATVBAHA. 114.303411, 2015.

7- MUKARRAM O., AKHTAR N., JUNAID A. and MOHYUDDIN A.: A study into the genetic basis of aspirin resistance in Pakistani patients with coronary artery disease. Pak. J. Pharm. Sci., 29: 1177-82. PMID: 27393450, 2016.

8- OZAKI K. and TANAKA T.: Molecular genetics of coronary artery disease. J. Hum. Genet., 61: 71-7. doi: 10.1038/ jhg.2015.70, 2016.

9- FLOYD C.N., MUSTAFA A. and FERRO A.: The PlA1/ A2 polymorphism of glycoprotein IIIa as a risk factor for myocardial infarction: A meta-analysis. PLoS One, 9: e101518. https://doi.org/10.1371/journal.pone.0101518, 2014.

10- MA W., WANG Y., HAN X., ZHU Y. and LIU N.: Associations between LPL gene polymorphisms and coronary artery disease: Evidence based on an updated and cumulative meta-analysis. Biosci. Rep., 38: BSR20171642. doi: 10.1042/BSR20171642, 2018.

11- XIANG Q., JI S., ZHANG Z., ZHAO X. and CUI Y.: Identification of ITGA2B and ITGB3 single-nucleotide polymorphisms and their influences on the platelet function. Biomed. Res. Int., 1: 1-11. doi: 10.1155/2016/ 5675084, 2016.

12- ALEKSIC N., JUNEJA H., FOLSOM A.R., AHN C., BOERWINKLE E., et al.: Platelet Pl (A2) allele and incidence of coronary heart disease: Results from the atherosclerosis risk in communities (ARIC) study. Circulation, 102: 1901-5. https://doi.org/10.1161/01.CIR.102 16.1901, 2000.

13- VELJKOVIC N., ZARIC B., DJURIC I., OBRADOVIC M., SUDAR-MILOVANOVIC E., RADAK D. and ISENOVIC E.R.: Genetic markers for coronary artery disease. Medicina, 54: 36. https://doi.org/10.3390/medicina 54030036, 2018.

14- WALTER D.H., SCHÄCHINGER V., ELSNER M., DIMMELER S. and ZEIHER A.M.: Platelet glycoprotein IIIa polymorphisms and risk of coronary stent thrombosis. Lancet, 350: 1217-9. Doi: 10.1016/S0140-6736(97)053993, 1997.

15- ZHANG Y., HAN Y., DONG L., YU H., CHENG L., ZHAO X. and DING M.: Genetic variation of ITGB3 is associated with asthma in Chinese Han children. PLoS One, 8: e56914. doi: 10.1371/journal.pone.0056914, 2013.

16-ZHU M.M., WEEDON J. and CLARK L.T.: Meta-analysis of the association of platelet glycoprotein IIIa PlA1/A2 polymorphism with myocardial infarction. Am. J. Cardiol., 86: 1000-5. Doi: https://doi.org/10.1016/S0002-9149 (00) 01136-X, 2000.

17- MIKKELSSON J., PEROLA M., LAIPPALA P., PENTTILA A. and KARHUNEN P.J.: Glycoprotein IIIa Pl (A1/A2) polymorphism and sudden cardiac death. J. Am. Coll. Cardiol., 36: 1317-23. https://doi.org/10.1016/S07351097(00)00871-8, 2000.

18- DUDAS K., LAPPAS G., STEWART S. and ROSENGREN A.: Trends in out-of-hospital deaths due to coronary 
heart disease in Sweden (1991 to 2006). Circulation, 123: 46-52. doi: 10.1161 /CIRCULATIONAHA.110.964999, 2011.

19- GÜNEL T., ANTAL A., ŞENTÜRK T., ÖZBASAK H.Ö., GÜMÜŞOGLU E., AŞKIN Ö.E., HOSSEINI M.K., DÖLEKÇAP I. and AYDINLI K.: The relation between the P1A1/A2 polymorphism of ITGB3 gene and myocardial infarction in elite athletes. Turkiye Klinikleri J. Med. Sci., 37: 68-73. Doi: 10.5336/medsci.2017-54901, 2017.

20- GROVE E.L., ORNTOFT T.F., LASSEN J.F., JENSEN H.K. and KRISTENSEN S.D.: The platelet polymorphism $\mathrm{PlA} 2$ is a genetic risk factor for myocardial infarction. J.
Intern. Med., 255: 637-44. Doi: 10.1111/j. 1365-2796. 2004.01327.x, 2004.

21- Le HELLO C., MORELLO R., LEQUERREC A., DUARTE C., RIDDELL J. and HAMON M.: Effect of PlA1/ A2 glycoprotein IIIa gene polymorphism on the longterm outcome after successful coronary stenting. Thromb. J., 5: 19. doi: 10.1186/1477-9560-5-19, 2007.

22- GALASSO G., SANTULLI G., PISCIONE F., De ROSA R., TRIMARCO V., PICCOLO R., CASSESE S., IACCARINO G., TRIMARCO B. and CHIARIELLO M.: The GPIIIA PIA2 polymorphism is associated with an increased risk of cardiovascular adverse events. BMC Cardiovasc. Disord., 16: 41-7. doi: 10.1186/1471-2261-10-41, 2010.

\section{تقيييم العلاقة بين تعدد الآثكال (PIA1/P1A2)

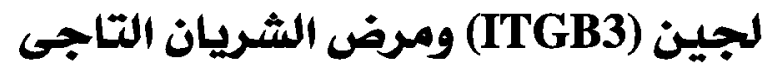

خلفية: يلعب تنشيط الصفائح الدموية وتكدسها دوراً حاسماً فى تخثر الدم الشريانى وبالتالى فى حدوث مرض الشريان التاجى. تبدآ

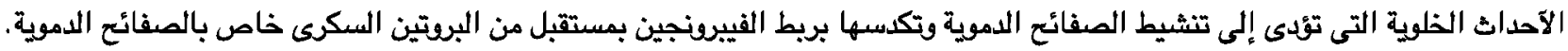
(glycoprotein IIb-IIIa) تعدد الآثكال آحادى النوكليوتيدات فى ITGB3 المشار إليه بمستضد الصفائح الدموية (P1A1/P1A2) (rs5918) بمرض الشريان التاجي.

$$
\text { الهدف: هدفت الدراسة الحالية إلى تقيّم العلاقة بين تعدد الآثكال (P1A1/P1A2) لجين (ITGB3) ومرض الثريان التاجى' }
$$

المواد وطرق البحث: آجريت الدراسة على 00 مريضاً ممن تم تشخيصهم كمالات تعانى من مرض الشريان التاجى إعتماداً على تصوير

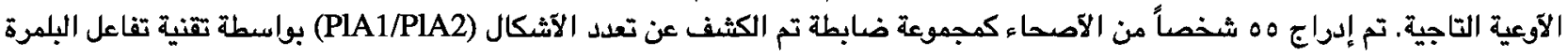
المتسلسل تقييد جزء طول تعدد الآثكال.

النتائج: آثبتت الدراسة الحالية آن النمط الجينى المتخالف (P1A1/P1A) والآليل (PlA2) كانوا آكثر تواتراً فى مرضى الثريان التاجى إنى

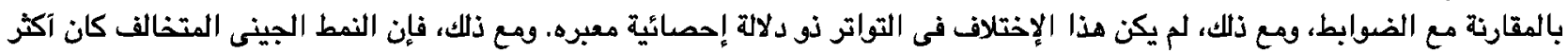

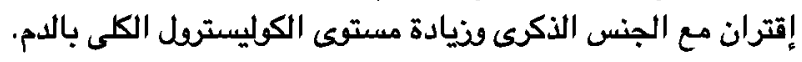

الخلاصة: لم تثبت هذه الدراسة علاقة النمط الجينى المتخالف (P1A1/P1A) بمرض الشريان التاجى رغم وجودة آكثر تواتراً فى المرضى 